\title{
EXPERIMENTS ON STRENGTHENED CONCRETE BEAMS WITH HYBRID STEEL-GRFP REBARS
}

\author{
Mounir M. Kamal* Mohamed A. Safan* Radwa A. Salama** \\ * Civil Engineering Department, Faculty of Engineering, Minoufiya University \\ ** Civil Engineer, Ministry of Water Resources and Irrigation, Shebin EL-Koom
}

\begin{abstract}
The corrosion problem occurs due to lack of protection given by the concrete cover. The problem of steel reinforcement corrosion has regularly meant improving the quality of concrete, but this approach has only limited success. The aim of the current work is to study the strengthening of concrete beams by increasing the reinforcement area utilizing GFRP rebars instead of conventional steel. In-house manufacturing of FRP bars has been described in this research using locally available glass fiber roving and polyester to produce GFRP reinforcing bars. The produced rebars are used as internal reinforcement in simply reinforced concrete beams. All test beams are reinforced with steel rebars with different reinforcement ratios. The concrete cover of these beams with low reinforcement ratios was removed and the longitudinal steel bars and stirnups were exposed. The added GFRP rebars were fixed either inside or outside the stirups and a suitable cover was provided. Different materials including high strength concrete, cement mortar and a special type of fibrous mortar known as engineered cementitious composite (ECC) mortar were used in casting the cover. Some test beams were designed to fail in shear and were strengthened by adding the extra GFRP bars and bonding external GFRP wraps to the beam sides in the shear span. The test beams were $100^{*} 150^{*} 1050 \mathrm{~mm}$ and were tested in flexure under 4-point bending up till failure. The structural behavior was investigated in terms of cracking and ultimate loads,
\end{abstract} deflections, and cracking patterns.

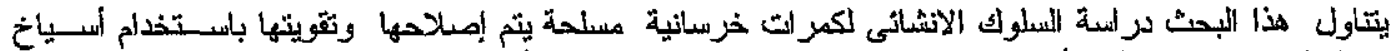

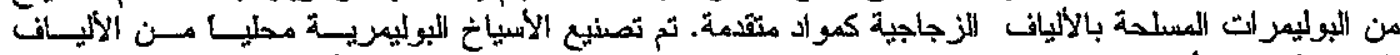

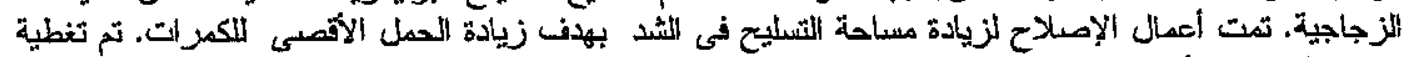

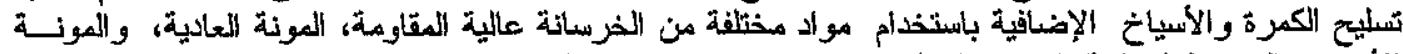

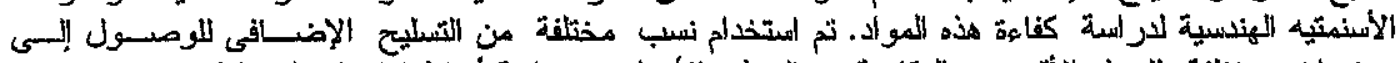

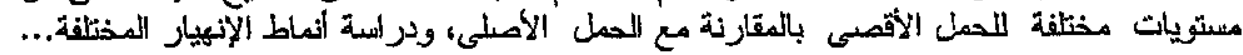

Keywords: RC beams, Strengthening, hybrid reinforcement, GFRP bars, engineered cementitious composites, fibers.

\section{INTRODUCTION}

Concrete structures in a corrosive environment are subjected to sever deterioration caused by reinforcement corrosion. The load carrying capacity, stiffness, and ductility of RC bearns is significantly influenced by the reduction of the reinforcement area and the change in the mechanical properties of steel and steel -concrete bond characteristics due to corrosion. Different repair and strengthening techniques are used to upgrade $\mathrm{RC}$ beams including concrete jackets with and without the addition of extra reinforcements and bonding external steel plates. The use of fiber reinforced polymers (FRP) in the form of external bonded plates to strengthen $\mathrm{RC}$ beams in shear and flexure has been known in the last 10 years and was found to be extremely efficient [1-2]. The non-corrosive nature of the FRP products makes these materials very attractive to avoid corrosion problems. The design and application considerations of FRP rebars as internal tension reinforcement has been addressed in the ACI 440.1R03 guide [3]. However, cases of using internal FRP bars to replace conventional steel in repair and strengthening works has not been fully studied yet.

The current research deals with the strengthening of RC beams with linited corrosion associated with reduction in the reinforcement area, while the mechanical properties of steel are not changed. Thus, the existing corroded steel can be a part of the reinforcement in a strengthened beam after appropriate protective treatment with epoxy coatings. In-house manufactured GFRP rebars are added to increase the reinforcement area and consequently the load carrying capacity of the strengthened beams.

\section{LITERATURE REVIEW}

With regard to the high cost of rebuilding deteriorated structures, rehabilitation of defected 
structural elements is preferable whenever possible. For this reason a need for efficient methods for repair and strengthening of exiting buildings has arisen. The development of new strengthening techniques is based on the development of application materials and equipment. To date, the materials used in rehabilitation works include cement mortars, cementitious materials modified with admixtures, polymer materials, resins for injecting cracks, adhesives, penetrating-in-surface sealers, steel plates and structural sections, prestressing tendons, steel and plastic fibers, and fiber reinforced polymers $[4,5]$. FRP materials are readily available in several forms ranging from FRP bars, factory-made laminates, structural shapes, and dry fiber sheets that can be wrapped to conform to the geometry of the structure. Such FRP products are ideally suited to use for strengthening and retrofitting applications of structures. In addition, FRP bars can replace steel as reinforcement in concrete structures, especially for structures subject to highly corrosive and aggressive environmental exposures [6].

The wide-spread implementation of FRP as a reinforcement for concrete structural members requires: (1) a comprehensive understanding of how these two materials behave together as a structural system, and (2) analytical techniques that reliably predict the composite behavior.

The cost effectiveness of FRP using carbon fibers as reinforcement is questionable with regard to the high cost of the fibers. Despite the unique high stiffness provided, designers have to be concerned about brittleness and impact resistance. On the other hand, glass fibers and polyester are commonly used in producing commercially available FRP bars because of the appealing combination of cost, processing ability and performance. However, the lower modulus of GFRP bars compared to steel and lack of ductility are yet major deficiencies [1]. This means that the use of GFRP rebars in strengthening works may only be expected to cause significant improvement in the load carrying capacity rather than stiffness as the modulus of elasticity of GFRP rebars is in the range of 35-51 GPa [3], which is only 1.5-2 times that of ordinary concrete. Further, experimental testing demonstrated that substituting of GFRP for steel rebars, on an equal area basis, typically results in significantly higher deflections with wider crack widths. As a consequence, deflection limitations will likely be an important parameter in design considerations $[7,8]$.

Flexural failure of concrete members reinforced with unidirectional mono-fiber FRP rebars can only be brittle. This occurs either as a result of concrete crushing or FRP tensile rupture. This behavior differs from the behavior of concrete beams under- reinforced with steel. In addition, shear capacity is also likely to be significantly reduced as a result of increased crack width and reduced size of compressive stress blocks due to the limited modulus of elasticity [9]. Numerous attempts were reported in the literature to improve the ductility of FRP bars by using soft core materials, hybridization of fibers with different modulus, and controlling the orientation of fibers in braided rebars. These different approaches were found to improve the ductility of the rebars to different levels yet; the tensile strength was reduced due to the use of soft cores or fibers [10-13].

The current research deals with the manufacturing of GFRP rebars to be used in the investigated strengthening schemes. Several attermpts were made towards in-house manufacturing of FRP rebars for research purposes utilizing the raw materials available in the local market and utilizing simple hand-operating as well as sophisticated equipment [13-15]. This experience with in-house manufacturing of FRP bars by applying the regular steps of molding and pultrusion techniques showed that the process was not fairly easy $[14,15]$. It was reported that, the fiber volume fraction in molding operations was limited to $25-38 \%$, while this ratio increased to $60 \%$ by applying the pultrusion technique, which improved greatly the tensile characteristics.

The proposed strengthening work involves casting fresh cementitious materials to cover the added rebars and adhere with the old concrete without using regular new-to-old epoxy adhesives. However, the ACI 546R-96 guide [5] states that preparation of the old concrete surface is required irrespective of the repair method used. Exiting surfaces to which new concrete is to be bonded without use of an epoxy agent must be clean, rough and dry. At first, all damaged or unbounded portions of exiting concrete must be removed by chipping hammers or other approved equipment, after which the surfaces must be exposed with approved water blasting equipment or any other approved method and then cleaned and allowed to dry thoroughly.

The new cover materials include high strength concrete, cement mortar and engineered cementitious composite (ECC) material. The later is a relatively new material used in specific applications with appealing mechanical properties for use in strengthening applications. The development of this material began in the early 1990 s at the University of Michigan, USA [16]. In terms of material constituents, ECC utilizes the materials of fiber reinforced concrete. Coarse aggregates are not used as they tend to adversely affect the unique ductile behavior of the composite. Typical values for the water/cement ratio, sand/cement ratio and fiber 
content are $0.5,0.5$ and 2 percent by volume, respectively. The most appealing property in ECC is that it strain-hardens rather than tension-softens after first cracking which means that ECC has a tensile stress-strain curve similar to that of as ductile metals [17]. Because of its appealing tensile and shear ductility, ECC mixes can replace the brittle concrete in specified applications as in seismic elements, concrete elements in composite structures, retrofitting of $\mathrm{RC}$ elements and as a durable cover for rebar corrosion control [16]. Also, it has been shown that ECC mixes provided an excellent shear behavior in simple beams reinforced with GFRP rebars compared to high strength concrete [18].

Finally, the experimental program involves the application of externally bonded GFRP plates to the sides of some beams along the shear span to increase the shear capacity. Numerous studies are reported in the literature demonstrating the robustness and efficiency of this technique $[1,19]$.

\section{AIM OF THE RESEARCH}

The current research is concerned with studying the efficiency of strengthening works involving the use of GFRP bars to increase the tension reinforcement area and consequently the load carrying capacity of simple beams under flexure loading. The extra added reinforcement are covered with different materials including high strength concrete, ordinary cement mortar and engineered cementitious composite (ECC) mortar. Different reinforcement ratios are used to upgrade the strengthened beams to different levels compared with control beams. The strengthening work also involves the use of external GFRP plates bonded along the shear span to upgrade shear deficient beams.

The philosophy behind the idea of combining GFRP rebars along with steel in the same section in strengthened beams is twofold: (1) to make use of the distinct properties of the two materials, i.e. the high tensile strength and non corrosive performance of the GFRP rebars placed near the outer surface and the ductility of the steel bars placed at a higher level and (2) the consecutive increments in the international prices of steel reinforcement encourage the efforts to find a suitable and technically sound alternative for partial or total replacement of steel.

\section{MATERIALS AND TEST SPECIMENS}

A total of thirteen reinforced concrete beams were tested [20]. Test beams were classified into three groups $\mathrm{C}$ (control beams), $\mathrm{F}$ (flexure strengthened beams) and $S$ (shear/flexure strengthened beams). Group (C) included five beams with different longitudinal reinforcement ratio. Three beams in this group have full web reinforcement in the form of closed stirrups, while the other two have inadequate web reinforcement and were designed to fail due to shear after being strengthened in flexure. Table (1) shows the reinforcement details for group (C) beams. Beams $\mathrm{C} 8 \mathrm{~W}, \mathrm{C} 10 \mathrm{~W}$ and $\mathrm{C} 13 \mathrm{~W}$ were reinforced with full web reinforcements and the reinforcement ratios in those beams were $0.77,1.2$ and 2.0 percent, respectively. Beams $\mathrm{C} 8$ and $\mathrm{C} 10$ were designed with lack in shear strength. Group (F) included a total of six beams with low reinforcement ratios of 0.77 and 1.2 percent. High strength concrete, cement mortar and engineered cementitious composite mortar were used as cover materials for the added reinforcement. Each material was used in a pair of beams with different reinforcement ratio. The beams in group (F) were prepared for strengthening by removing the concrete cover to expose the longitudinal steel reinforcement. $50 \mathrm{mms}$ of concrete were removed, so that $20 \mathrm{mms}$ were available to surround the steel reinforcement using the new cover material. Beams with the lower reinforcement ratio $(0.77 \%)$ were strengthened by adding 2 No. 3 GFRP rebars. The two rebars were tied outside the closed stirrups and therefore, the cross section of those beams was increased to $10 \times 16$ compared to $10 \times 15$ in the control mixes. Only one GFRP rebar was added when the reinforcement ratio is increased to 1.2 percent in beams F10C, F10M and F10E, Fig. (1). In this case the cross section was kept the same, as the added rebar could be inserted inside the stirrups as shown in Table (1).

Group (S) included two beams with 0.77 and 1.2 percent reinforcement ratio. High strength concrete was used as a cover material. Each beam was reinforced with only three stirrups intended to hold the longitudinal reinforcement in place. Group (S) beams were reinforced in both flexure (by adding either one or two longitudinal rebars) and in shear by bonding four $(15 \times 33 \mathrm{~cm})$ GFRP plates. The plates were bonded to the side face between the support and the applied load, Fig. (2).

All beams were tested to ultimate load in fourpoint bending over a simple span of $910 \mathrm{~mm}$ and a shear span of $330 \mathrm{~mm}$, Fig. (3). Both ends of the beam were free to rotate and translate under load.

The load was applied by means of a $150 \mathrm{kN}$ capacity flexural machine equipped with a digital control console. The load was applied in increments of $2.0 \mathrm{kN}$. Midspan deflection was recorded at each load step using a dial gage. 
M. M. Kamal, M. A. Safan, R. A. Salama, "Experiments on Strengthened Concrete Beams with Hybrid ..."

Table 1 Details of the tested beams

\begin{tabular}{|c|c|c|c|c|c|c|}
\hline BEAM & $\begin{array}{l}b \times t \\
(\mathrm{~cm})\end{array}$ & $\begin{array}{c}\text { Cover } \\
\text { Material }\end{array}$ & $\begin{array}{l}\text { Added } \\
\text { GFRP } \\
\text { Rebars } \\
\end{array}$ & Stimups? & $\begin{array}{l}\text { Strengthening } \\
\text { Configuration }\end{array}$ & $\begin{array}{l}\text { Total Reinf. } \\
\text { Ratio, \% }\end{array}$ \\
\hline $\mathrm{C} 8 \mathrm{~W}^{*}$ & \multirow{3}{*}{$10 \times 15$} & \multirow{3}{*}{$\begin{array}{l}\text { control } \\
\text { beams }\end{array}$} & -- & 508 & \multirow{3}{*}{$\underset{b}{b} t$} & 0.77 \\
\hline Clow & & & - & 508 & & 1.20 \\
\hline $\mathrm{C} 13 \mathrm{~W}$ & & & $\cdots$ & $6 \varnothing 8$ & & 2.0 \\
\hline $\mathrm{F} 8 \mathrm{C}$ & \multirow{3}{*}{$10 \times 16$} & HSC & \multirow{3}{*}{$\begin{array}{l}2 \text { No. } 3 \\
\text { rebars }\end{array}$} & \multirow{3}{*}{508} & & \multirow{3}{*}{1.70} \\
\hline F8M & & $\mathrm{CM}$ & & & & \\
\hline F8E & & $\mathrm{ECC}$ & & & & \\
\hline F10C & \multirow{3}{*}{$10 \times 15$} & $\mathrm{HSC}$ & \multirow{3}{*}{$\begin{array}{l}\text { 1. No. } 3 \\
\text { rebar }\end{array}$} & \multirow{3}{*}{$5 \emptyset 8$} & & \multirow{3}{*}{1.75} \\
\hline FIOM & & $\mathrm{CM}$ & & & & \\
\hline FlOE & & $\mathrm{ECC}$ & & & & \\
\hline $\mathrm{C} 8$ & \multirow{2}{*}{$10 \times 15$} & \multirow{2}{*}{$\begin{array}{l}\text { control } \\
\text { beams }\end{array}$} & \multirow{2}{*}{-} & \multirow{2}{*}{306} & \multirow{2}{*}{$\begin{array}{l}1 \\
1\end{array}$} & 0.77 \\
\hline $\mathrm{C} 10$ & & & & & & 1.20 \\
\hline S8 & $10 \times 16$ & $\mathrm{HSC}$ & $\begin{array}{l}2 \text { No. } 3 \\
\text { rebars }\end{array}$ & $3 \emptyset 6$ & & 1.70 \\
\hline S10 & $10 \times 15$ & $\mathrm{HSC}$ & $\begin{array}{l}1 \text { No. } 3 \\
\text { rebar }\end{array}$ & 306 & & 1.75 \\
\hline
\end{tabular}

HSC: high strength concrete

CM: cement nottar

ECC: engireered cementitious composite

* the number indicate the diameter of the reinforcing bas

t number of stirnups along the shear span

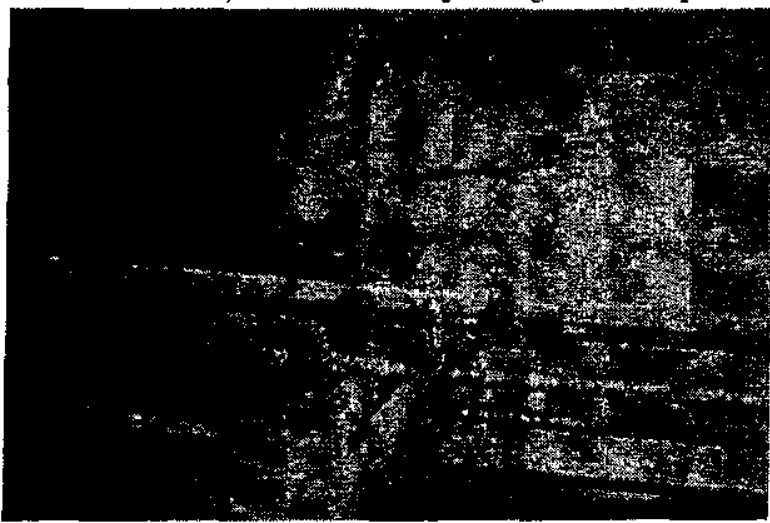

Fig. 1: Inserting the extra longitudinal GFRP rebar inside the stirrups

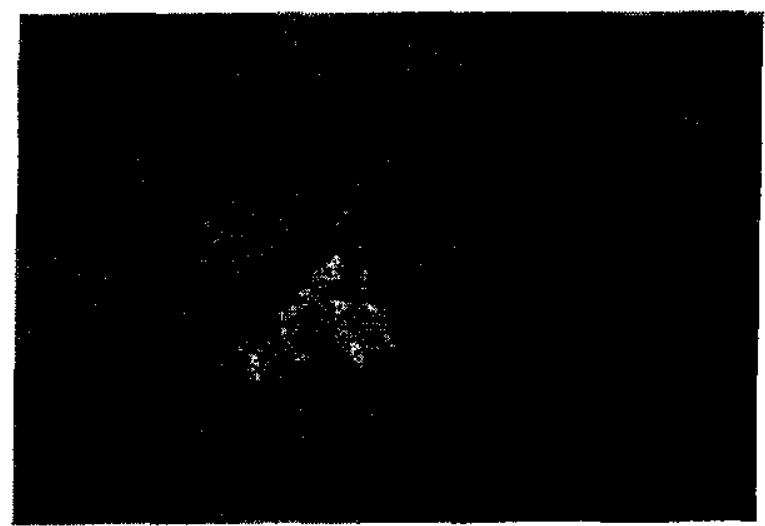

Fig. 2: Bonding layers of polyester infused fiber glass woven roving fabric along the shear span. 


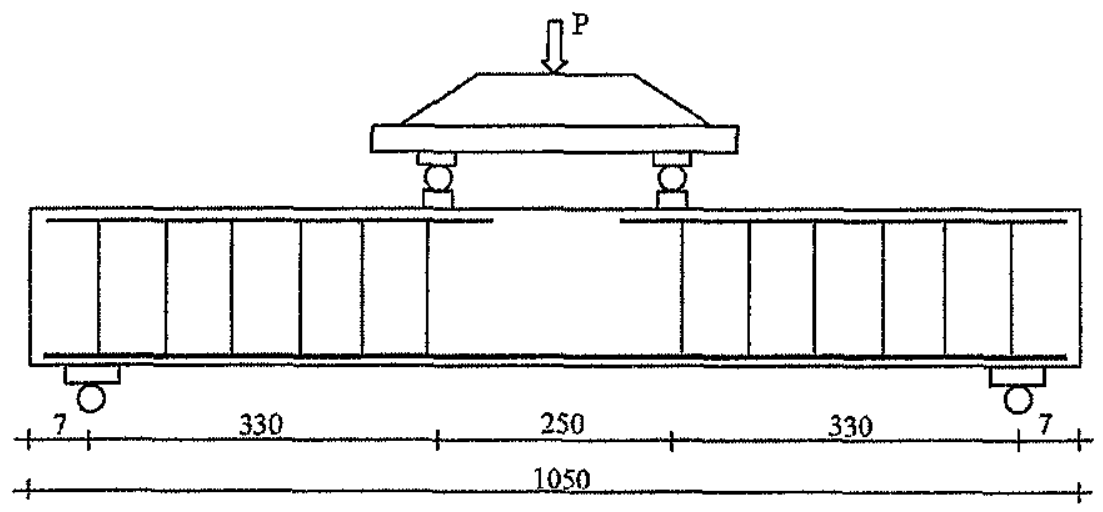

Fig. 3: Dimensions of test specimen and loading configuration.

\subsection{Materials}

Concrete: an ordinary concrete mix with a characteristic strength of $30 \mathrm{MPa}$ was used in casting the test specimens. Ordinary Portland cement type $I$, crushed dolomite with a nominal maximum size of $12.5 \mathrm{~mm}$, and siliceous graded sand with a fineness modulus of 2.65 were used. Standard $150 \mathrm{~mm}$ cubes and $100 \times 100 \times 500 \mathrm{~mm}$ prisms were cast to determine the compressive strength and modulus of rupture at 28 days. The concrete mix proportions and mechanical properties of concrete are given in Tables $(2,3)$.

Cover materials: The extra added GFRP rebars were covered using three different materials: high strength concrete, cement mortar and engineered cementitious composite mortar. The high strength concrete mix had a characteristic strength of $55 \mathrm{MPa}$ and was proportioned using the same materials as in the ordinary mix. The water cement ratio was 0.42 and a high range water reducer was used to achieve a suitable workability.

The cement mortar had a cube compressive strength of $35 \mathrm{MPa}$ at 28 days. The cement/sand ratio was $1 / 3$ by weight. The water/cement ratio was 0.4 and a high range water reducer was used to improve the workability of the mortar. The engineered cementitious composite (ECC) mortar was proportioned using Portland cement Type I, with water/cement and sand/cement ratios of 0.5 . A high range water reducer was added at a dose of 0.4 percent by weight of cement and the fibers fraction was about 1.2 percent of the $\mathrm{mix}$ volume. These proportions yielded an ECC mix with cube strength of $40 \mathrm{MPa}$ at 28 days. The compressive strength and modulus of rupture for the cement mortar and the ECC mixes were determined using $50 \mathrm{~mm}$ cubes and $40 \times 40 \times 160 \mathrm{~mm}$ prisms according to the testing procedures of ASTM C109M-99 and ASTM C348$97[21,22]$. The mix proportions for the cover materials and their mechanical properties are shown in Tables $(2,3)$.

Fiber mesh: The fibers used in the ECC mixes had a trade name fiber-mesh $300-\mathrm{e} 3$ produced by SI Concrete Systems, USA. The 20-mm long polypropylene fibers are used as microreinforcement for concrete and mortar to control the formation of cracks. Other benefits associated with the use of these fibers include improved impact resistance, increased cohesion, and reduced plastic shrinkage and bleeding. The fibers have the advantages of being electrically non-conductive with high resistance to acid, alkaline and salt attacks. According to the manufacturer data sheet the fibers have a specific gravity of 0.91 and comply with ASTM C1116-00 Type III fibers [23].

Table 2: Constituents of concrete and cover materials $\left(\mathrm{kg} / \mathrm{m}^{3}\right)$

\begin{tabular}{|c|c|c|c|c|c|c|}
\hline Material & Cement & water & Sand & Dolomite & HRWR & Fibers \\
\hline NSC & 350 & 190 & 712 & 1068 & - & - \\
\hline HSC & 400 & 180 & 695 & 1042 & 3.2 & - \\
\hline CM & 535 & 214 & 1600 & - & 8.9 & - \\
\hline ECC & 1000 & 500 & 500 & - & 40 & 11 \\
\hline
\end{tabular}


Table 3: Mechanical properties of concrete and cover materials

\begin{tabular}{|l|c|c|}
\hline Material & $f_{c u}(\mathrm{MPa})$ & $f_{r}(\mathrm{MPa})$ \\
\hline $\mathrm{NSC}$ & 30 & 2.9 \\
\hline $\mathrm{HSC}$ & 55 & 4.3 \\
\hline $\mathrm{CM}$ & 35 & 4.0 \\
\hline $\mathrm{ECC}$ & 40 & 6.5 \\
\hline
\end{tabular}

Chemical admixtures: One type of chemical admixtures was used with a trade name Addicrete$\mathrm{BDF}$, which is classified as a high range water reducer meeting the requirements of ASTM C-33 specification (type $A$ and $F$ ). The admixture is a brown liquid with a specific gravity of $1.17 \mathrm{~kg} / \mathrm{lit}$.

Steel: two types of reinforcing steel bars were used. Mild steel bars with a yield strength of $330 \mathrm{MPa}(6$ \& 8 -tnm nominal diameter for stirrups and longitudinal bars) and high tensile deformed bars with a yield strength of $520 \mathrm{MPa}$ (10-mm nominal equivalent diameter) for longitudinal bars.

\section{Fiber Reinforced Polymer Composites}

GFRP bars: In-house manufactured 9.5-num FRP rebars were produced and tested in tension according to the procedures described in Ref. [13]. A simple .hand-operated equipment was used to saturate the glass rovings in a polyester basin and then twist the fibers at an off-axis angle of 30 degrees to squeeze excessive resin. The produced bars were coated with sand. Sand coating was found to be efficient in developing higher bond strength compared to conventional steel with discrete ribs [13]. The fiber volume fraction in the produced rebars was about $63 \%$. The test results showed that the produced bars had a tensile strength of $750 \mathrm{MPa}$, a modulus of elasticity of $42 \mathrm{GPa}$ and failed at a strain of 0.018 , as can be seen in Fig. (4).

GFRP reinforcing plates: the GFRP plates were used as externally bonded reinforcement to increase the shear capacity in beams S8, S10 that were deficient in shear. The plates are made of fiber glass woven roving fabric with a thickness of $0.5 \mathrm{~mm}$ and a weight of $450 \mathrm{gm} / \mathrm{m}^{2}$. Two fabric layers $(150 \times 330$ $\mathrm{mm}$ ) were successively applied to the surface after being thoroughly infused in polyester, so that the total thickness of the hardened plate was $1.0 \mathrm{~mm}$.

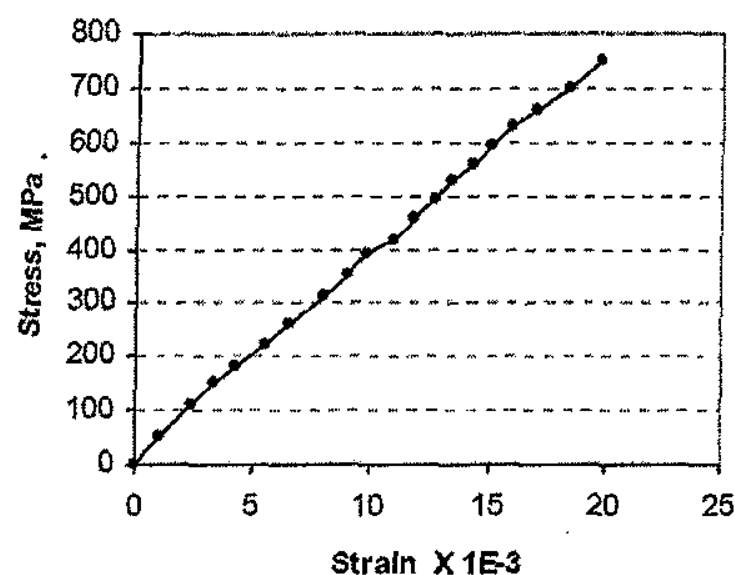

Fig. 4: Stress-strain relationship for No. 3 GFRP rebar

\section{ANALYSIS OF TÉST RESULTS}

The experimental work aimed to investigate the structural behavior of simply supported concrete beams reinforced with steel and GFRP rebars. Test parameters included different ratios of the main steel reinforcement and different steel/GFRP reinforcement ratios. Three types of cover materials including high strength concrete, cement mortar and engineered cementitious composite mortar were applied. The efficiency of the different strengthening schemes is evaluated based on the structural behavior in terms of cracking and ultimate loads, load deflection response, cracking patterns and failure modes.

The results reported in Table (4) indicate that the cracking load was not affected by the added GFRP rebar(s). Also, the cracking load remained the same when high strength concrete and cement mortar were used as cover materials. Significant increase in the cracking load can be observed when ECC was used. The cracking load in beam F8E and F1OE was 38 and 28 percent higher compared to the cracking load in the control beams $\mathrm{C} 8 \mathrm{~W}$ and $\mathrm{C} 10 \mathrm{~W}$, respectively.

The ultimate loads in Table (4) show that the ultimate load in beams F8C, F8M and F8E $($ GFRP/steel reinforcement ratio $=1.4)$ increased by 109,75 and 132 percent, respectively compared to the ultimate load in the control beam C8W, while the average ultimate load in beams F10C, F10M and F10E (GFRP/steel reinforcement ratio $=0.5$ ) was 27 higher compared to the control beam $\mathrm{C} 10 \mathrm{~W}$. It can be seen that the ultimate load was independent of the cover material as the three beams F10C, F10M and F10E failed in flexure due to concrete crushing in the maximum moment region. On the other hand, beams F8C, F8M and F8E failed due to bond failure between the GFRP rebars and the cover material, 
which explains the influence of the cover material on the recorded ultimate loads in these beams.

Placing two GFRP rebars near the outer surface in beams F8C, F8M and F8E significantly increased the number of cracks that were uniformly distributed along the whole span as can be seen in Fig. (5. b). The number of cracks increased in beam F8E up to more than five times compared to beam $\mathrm{C} 8 \mathrm{~W}$; demonstrating the potential of the ECC material in controlling the cracking width.

Table 4: Cracking and ultimate loads and failure modes for test beams

\begin{tabular}{|l|c|c|c|}
\hline Beam & $\begin{array}{c}\text { Cracking } \\
\text { load, ton }\end{array}$ & $\begin{array}{c}\text { Ultimate } \\
\text { load, ton }\end{array}$ & $\begin{array}{c}\text { Failure } \\
\text { mode }\end{array}$ \\
\hline C8W & 1.6 & 2.73 & F \\
\hline C10W & 1.8 & 5.40 & F \\
\hline C13W & 2.0 & 8.79 & SC \\
\hline F8C & 1.6 & 5.70 & B \\
\hline F8M & 1.6 & 4.78 & B \\
\hline F8E & 2.2 & 6.35 & B \\
\hline F10C & 1.8 & 6.92 & F \\
\hline F10M & 1.8 & 6.80 & F \\
\hline F10E & 2.3 & 6.91 & F \\
\hline C8 & 1.6 & 2.90 & F \\
\hline C10 & 1.8 & 5.76 & F \\
\hline S8 & 1.8 & 5.88 & B \\
\hline S10 & 1.9 & 6.39 & B \\
\hline
\end{tabular}

The load-deflection curves in Fig. (6.a) show typical three stage load-deflection response that corresponds to the pre-cracking, post-cracking and yield stages for the control beams $\mathrm{C} 8 \mathrm{~W}, \mathrm{C} 10 \mathrm{~W}$ that failed in flexure due to concrete crushing the maximum moment region. Fig. (6.b) shows that the stiffness of the strengthened beams F8C, F8M and F8E was not increased compared to the stiffness of the control beam. However, the beams developed three stage load-deflection curves indicating yielding of the steel reinforcement without developing explicit yield plateau as in the control beam C8W. Once the steel yielded, the load was transferred to the GFRP rebars and thus the applied load increased linearly with deflection until failure that occurred suddenly due to bond failure along the GFRP rebars. Because the load transferred early to the GFRP rebars (at about 60 percent of the ultimate load), the beams showed sufficient ductility expressed by the ductility index (deflection at ultimate relative to the deflection at yield). Similar response can be observed in Fig. (6.c) for beams F10C, F10M and F10E, yet steel yielding occurred at a higher loading level and the yield plateau was observed as the strengthened beams failed in flexure due to concrete crushing in the maximum moment ratio. Fig. (6.d) shows that the load-deflection response of beams
F8C and F8E (total R.R $=1.7 \%$ ) was very close to that of beam C10W (R.R $=1.2 \%$ ), demonstrating that steel has to be replaced with a higher amount of GFRP reinforcement to maintain the structural behavior. The shear strengthened beams $\mathrm{S} 8$ and $\mathrm{S} 10$ in Fig. (6. e, f) had developed similar load-deflection curves as beams $\mathrm{F} 8 \mathrm{C}$ and $\mathrm{F} 10 \mathrm{C}$ with close strength levels, stiffness and ductility. However, theses two beams failed due to bond failure. It was noticed that the formation of shear cracks was inhibited in the shear span due to the side bonded plates, while longitudinal cracks occurted along the reinforcement leading finally to bond failure.

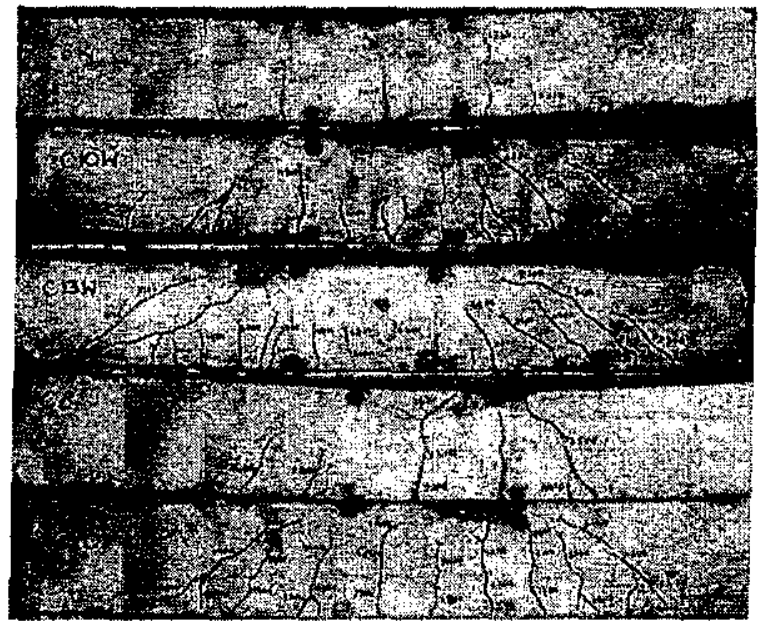

Fig. 5.a: Cracking pattern for control beams

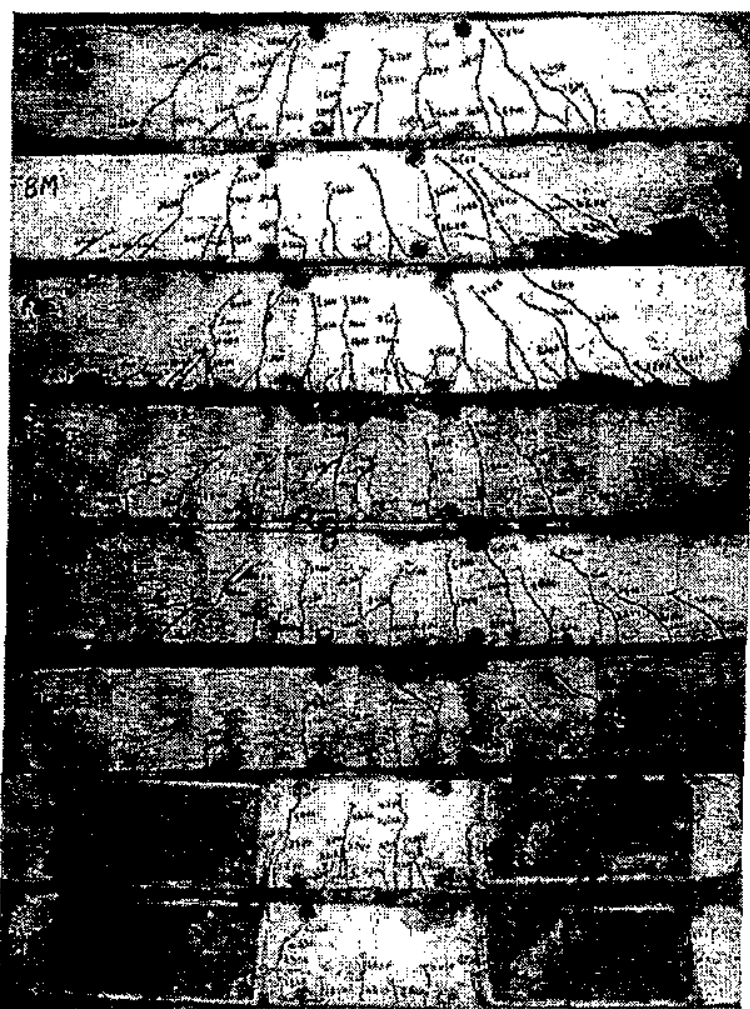

Fig. 5.b: Cracking pattern for strengthened beams. 
(a)

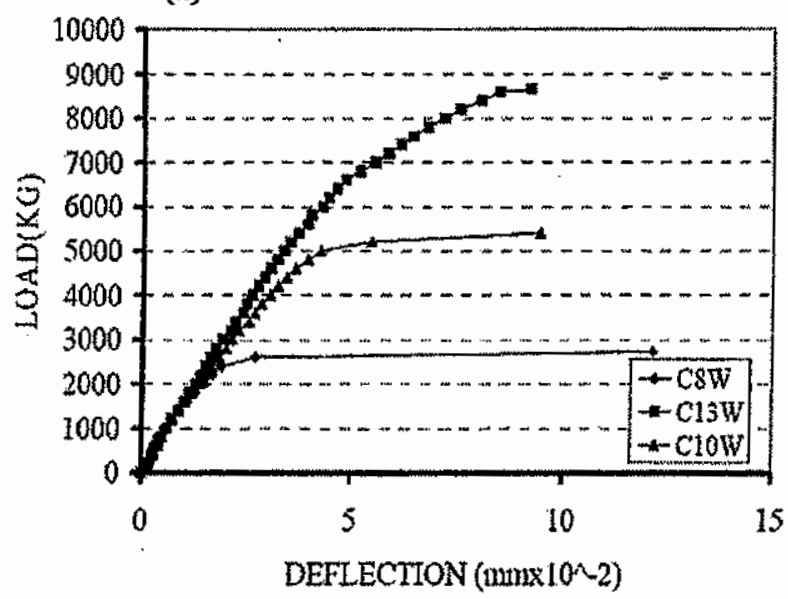

(c)

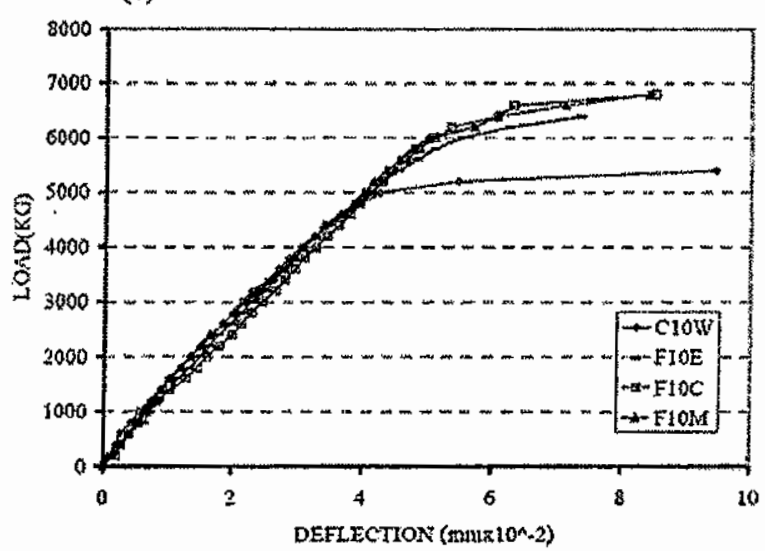

(e)

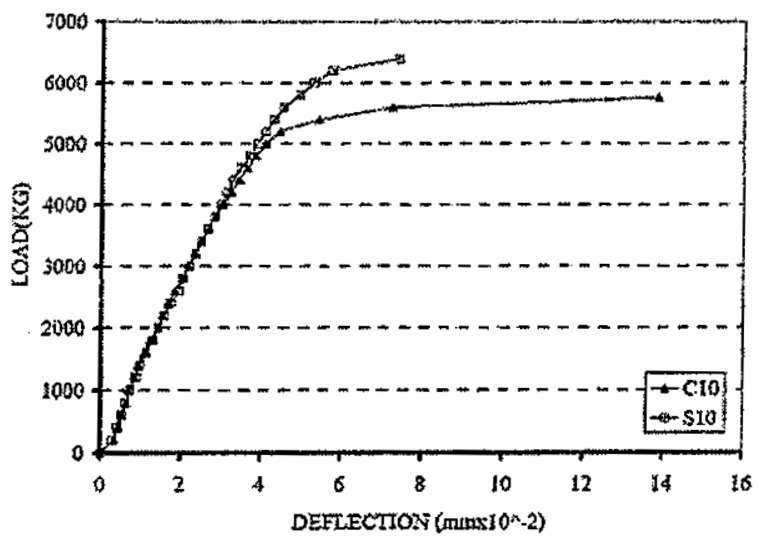

(b)

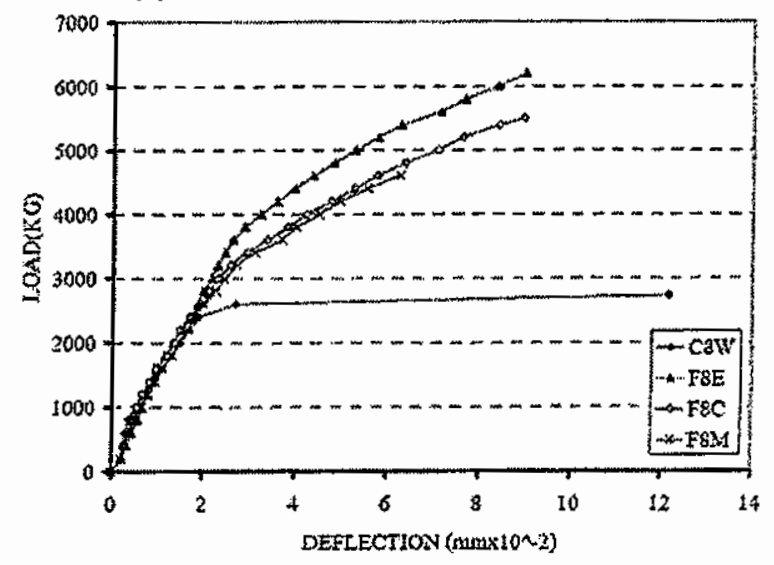

(d)

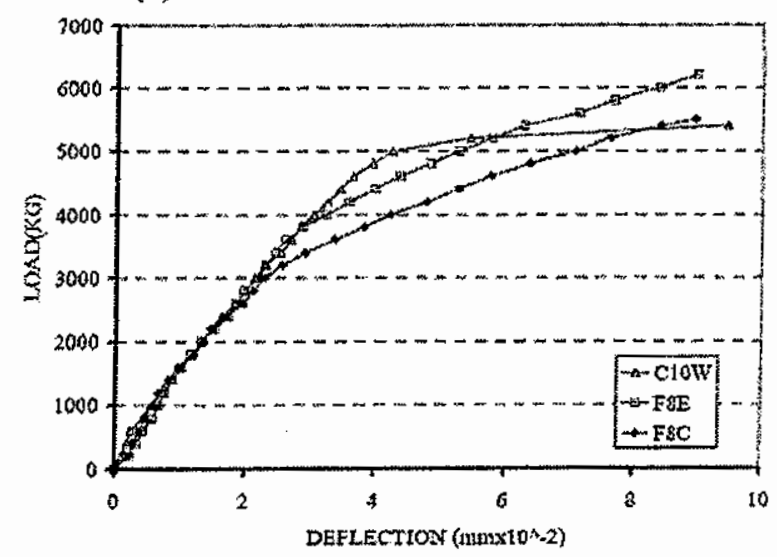

(f)

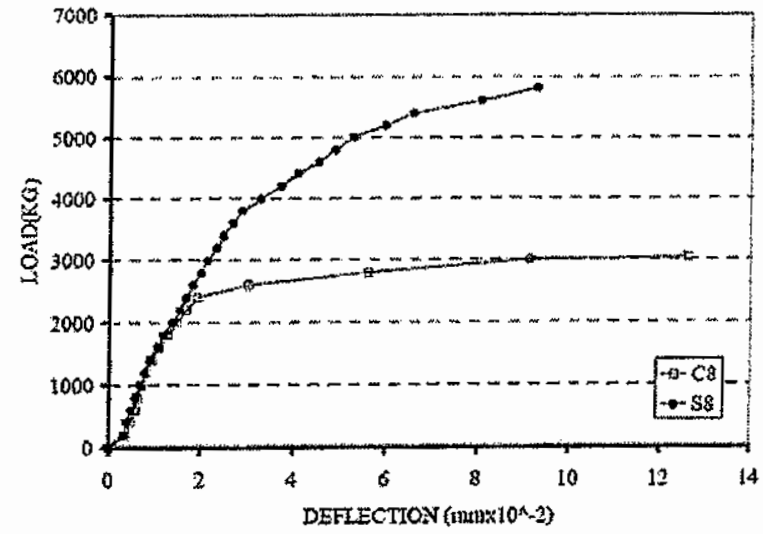

Fig. 6: Load - midspan deflection curves for test beams 


\section{CONCLUSIONS}

Based on the results of the experimental work described in this research, the following main conclusions can be drawn:

1. Adding extra GFRP rebars enclosed in the stirrups improved the flexural capacity, while the stiffness did not increase because of the low modulus of the GFRP rebars.

2. The relative amount of each type of reinforcement is an important parameter to ensure yielding of the steel reinforcement before either rupture of the GFRP rebar or concrete crushing occurs to obtain a ductile failure. This parameter also controls the amount of strength gain in the strengthened beams.

3. Fixing the added rebars outside the stirnups led to a premature failure due to bond failure between the added rebars and the cover due to the limited cover thickness.

4. In all the strengthened beams, the initial stiffness was not influenced by the type of the cover material.

5. The use of engineered cementitious composite mortar significantly improved the cracking characteristics in terms of cracking loads, mode of failure and distribution of cracks along the beam span due to its superior tensile properties.

6. It is possible to fix the extra reinforcing bars outside the closed stirrups, provided that a high quality cover material is used such as engineered cementitious composite mortars.

7. In all test beams, no signs of bond failure between the old and new cover material were observed, despite the fact that no new-to-old adhesive was used.

\section{REFERENCES}

[1] ACl 440R-96, (1996): "State-of-the-art report on fiber reinforced plastic (FRP) reinforcement for concrete structures" ACI Committee 440,65 pp.

[2] ACI 440.2R-02, (2002): "Guide for the design and construction of externally bonded FRP systems for strengthening concrete structures" American Concrete Institute (ACI), Committee $440,1^{\text {st }}$ Edition, October 2002, $47 \mathrm{pp}$.

[3] ACI 440.1R-03, (2003): "Guide for the design and construction of concrete reinforced with FRP bars" American Concrete Institute (ACI), Committee 440, 42 pp.

[4] Academy of Science and Technology, (1991): "Seminar of repair and strengthening of reinforced concrete structure", Final Report, Vol. 2., April 1991.
[5] ACI 546R-96, (1996): "Concrete repair guide" American Concrete Institute (ACI), Committee $546,41 \mathrm{pp}$.

[6] Triantifillou, T. C., (2002): "Fiber reinforced polymer composites: State-of-the-art review" Journal of Composites in Construction, Vol. 6, No. 2, pp. 73-87.

[7] Benmokrane, B.; Chaallal, O.; and Masmoudi, R., (1996): "Flexure strength of concrete beams reinforced with FRP reinforcing bars" ACl Structural Journal, Vol. 93, No. 1, pp. 46-55.

[8] Safan, M. A.; and Afify, M. R.,(2005): 'Behavior of concrete beams reinforced with in-house manufactured GFRP bars" Proceedings of the Fourth Middle East Symposium on Structural Composites for Infrastructure Applications, MESC-4, Alexandria, Egypt, May 20-23, 2005.

[9] Zhao, W.; Maruyama, k.; and Suzuki, H., (1995): "Shear behavior of concrete beams reinforced by FRP rods as longitudinal and shear reinforcement" Proceedings of the Second International RILEM Symposium on nonmetallic (FRP) Reinforcement for Concrete Structures (FRPRCS-2), Ghent, Belgium, pp. 352-359

[10] Bakis, C. E., Nanni. A. and Terosky, J. A. (1996) "Smart pseudo-ductile reinforcing rods for concrete: manufacture and test" Proceedings of the 1st International Conference on Composites in Infrastructures, Editor: Saadatmanesh, H. and Ehsani, M. R., Tucson, Arizona, pp. 95-108.

[11]Harris, H. G., Somboonsong, W. and Ko, F. K. (1998): "New ductile hybrid FRP reinforcing bar for concrete structures" Journal of Composites of Construction, Vol. 2, No. 1, pp. 28-37.

[12] Sadek, E. F. (2004): "Studying the use of fiber reinforced plastics in producing reinforcing bars for concrete" M. Sc. Thesis, Ain Shams University, Cairo, Egypt, 216 pp.

[13] Safan, M. A. (2004): "Mechanical properties of locally produced hybrid FRP bars as concrete reinforcement" International Conference on Future Vision and Challenges for Urban Development, Housing \& Building Research Center (HBRC), Cairo, Egypt, 20-22 December 2004. HBRC Journal, Vol. 1, No. 1, December 2004, ISSN 12479/2004, 1-13.

[14] Okba, S.; Elshafie, H.; Fathey, A.; and Abdel Zaher, Y. (2002): "Properties of in-house manufactured FRP rebars" Proceedings of the Third Middle East Symposium for Infrastructure applications, 17-20 December 2002, Aswan, Egypt. 
[15]Riad, A.; Abdel Naby, S.; Ghanem, G.; and Salama, A. (2002) "Local manufacture and" properties of glass fiber reinforced polymers rebars" Proceedings of the Third Middle East Symposium for Infrastructure Applications

[16] Li, V. C.; and Tetsushi, K., (1998): "Engineered cementitious composites for structural applications" Journal of Materials in Civil Engineering" Vol. 10, No. 2, pp. 66-69.

[17]Li, V. C., (1993): "From Micromechanics to structural engineering: the design of cementitious composites for civil engineering applications" Journal of Structural Mechanics and Earthquake Engineering, Vol. 10, No. 2, pp. $37-48$.

[18]Li, V. C.; and Wang, S., (2002): "Flexural behaviors of glass fiber reinforced polymer (GFRP) reinforced engineered cementitious composite beams" ACI Materials Journal, Vol. 99, No. 1, Jan-Feb. 2002, pp. 11-21.
[19] Safan, M. A. (2006): "Shear Strengthening of reinforced concrete beams using GFRP wraps" Acta Polytechnica, Vol. 46, No. 1, Feb. 2006, pp. 24-32.

[20] Salama, R. A., (2007): "Rehabilitation of reinforced concrete beams using composite materials" M. Sc. Thesis, Minoufiya University, Egypt, 2007, 153 pp.

[21] ASTM C109M-99, (1999) "Standard test method for flexure strength of hydraulic cement mortars" ASTM Standards, Published May 1999, 6 pp.

[22] ASTM C348-97, (1997) "Standard test method for compressive strength of hydraulic cement mortars" ASTM Standards, Published June 1998, $6 \mathrm{pp}$.

[23]ASTM C1116-00 (2000) "Standard specification of fiber reinforced concrete and shotcrete" ASTM Standards, Published November 2000, 8 pp. 